\title{
Antiviral activity of Curcuma longa against Newcastle disease virus (in vitro and in vivo studies)
}

\author{
S. M. Tamam*, H. M. Madbouly, Fadwa Amin \\ Department of Virology, Faculty of Veterinary Medicine, Beni-Suef University, Beni-Suef, Egypt.
}

\begin{abstract}
The antiviral activity of Curcuma longa against NDV on vero cell culture and in infected chicken was observed. The obtained results showed that low concentration of Curcuma longa $\mathbf{0 . 2 5 \%}$ did not produce cytotoxicity on the vero cell. The effect of Curcuma longa on NDV titre was studied and the results revealed clearly that chickens treated with $1 \%$ Curcuma longa as Prophylactic also showed higher protection rate $(90 \%)$, the chickens that treated with $0.5 \%$ Curcuma longa showed protection rate $(80 \%)$. Chicks that infected with NDV without treatment with Curcuma longa showed lower protection rate $(8 \%)$. The chickens infected then treated with $1 \%$ Curcuma longa showed protection $(65 \%)$ and the chickens infected then treated with $0.5 \%$ Curcuma longa showed protection (40\%).
\end{abstract}

Newcastle disease (ND) is a serious and destructive infectious disease of birds. It is regarded as a major problem facing poultry keeping all over the world whether in large or small scale. Vaccination against NDV is cost and causes some problem. Vaccination with live virus vaccines may play an important role in control of NDV in the infected areas, problems may occur, especially adverse vaccine reactions, such as mild respiratory disease or depressed egg production (Stone, 1997). There is currently a worldwide use of herbal preparations and the active ingredients isolated from medicinal plants in health care. One of these plants is Curcuma longa. The dried rhizome of Curcuma longa, which has been used for countries as a spice, food preservative and a coloring agent, has been found to be a rich source of beneficial phenolic compounds known as the curcuminoids. The active constituents of turmeric are the flavonoid curcumin and volatile oils including tumerone, atlantone, and zingiberone. Other constituents include sugars, proteins, and resins. The bestresearched active constituent is curcumin, which comprises 0.3 to 5.4 percent of raw turmeric (Leung, 1980). So the objective of this work to study the effect of Curcuma longa on RNA virus ( New castle disease virus) in vivo and in vitro.

\section{Materials and methods}

Chicks. A total number of 300 one -day- old chicks were obtained from private hatchery in Beni Suef baladi breeders. They were floor reared, fed on a commercial poultry ration and kept under good hygienic condition throughout the experiment.

Curcuma Longa powder. The powder was purchased from commercial sources and used at concentration $0.25 \%$ on vero cells and at concentration $1 \%$ and $0.5 \%$, by thoroughly mixed with ration as feed additives.

Biochemical kits. It was used for estimation of total protein and albumin it was purchased from Diamond Company Lot NO 00476544

Detection of Curcuma longa cytotoxicity.

Preparation of different concentration of Curcuma longa in E 199 medium. In separate vessels 250, 500, 1000, 2000 and $3000 \mathrm{mg}$ of curcuma longa were dissolved in $50 \mathrm{ml}$ of D.W by boiling. Each vessel was completed to $100 \mathrm{ml}$ by addition blank E199 medium .This solution was centrifuged at $1500 \mathrm{rpm}$ for $10 \mathrm{~min}$. and the supernatant was filtrated.

Detection of 50\% toxic dose of Curcuma longa on Vero cells. In 96 tissue culture plate (96 wells) with confluent monolayer of vero cells, different concentration of Curcuma longa were added each concentration / each row of the microtitre plate as follows $0.25,0.5,1,2,3 \%$ in row A, B, C, D, E and the last three rows were kept untreated as cell control. The plats were incubated at $37^{\circ} \mathrm{C}$ and $5 \%$ $\mathrm{Co}_{2}$ and $80 \%$ humidity for about 6 days with daily examination for the presence of cytopathic effects. Cytopathogencity of NDV treated with Curcuma longa on Vero cells. It was done according to (Sebla et al., 2007). Flat bottom micro titer plat contained $90 \%$ confluence of Vero cells was used. The medium were poured off in 24-wells and $100 \mu \mathrm{l}$ of maintenance medium was added to each well. In each well of the first row 50 $\mu 1$ of $10^{7}$ of Newcastle disease (virus) were added

* Corresponding author. Tel.: +20 0822322066 ;

Fax+20 082 23279082:

E-mail address: stamam@bsu.edu.eg

(Sabry M. Tamam). 
Table (1): Treatment and infection of chicks used in this study.

\begin{tabular}{lccc}
\hline Group & Curcuma longa & NDV infection & NO. of chicks \\
\hline G1- infected not treated & - & + & 50 \\
G - treated with 1\% then infected & $+1 \%$ & + & 50 \\
G3 - treated with 0.5\% then infected & $+0.5 \%$ & + & 50 \\
G4 - infected then treated with 1\% & $+1 \%$ & + & 50 \\
G5 - infected then treated with 0.5\% & $+0.5 \%$ & + & 50 \\
G6- control treated & $+1 \%$ & - & 25 \\
G7 - non infected non treated & - & - & 25 \\
\hline
\end{tabular}

and the second row $50 \mu 1$ of $0.25 \%$ concentration of Curcuma longa (curcuma) were added.

In the third row $50 \mu 1$ of $10^{7}$ of Newcastle disease virus and $50 \mu 1$ of Curcuma longa (virus + Curcuma longa) were added while in the forth row only $50 \mu 1$ of maintenance media (control) were added. The plate was then incubated in $\mathrm{CO} 2$ incubator at $37^{\circ} \mathrm{C}$ and $5 \% \mathrm{CO} 2$ with daily observation for cytopathic effect till $120 \mathrm{hrs}$.

Detection the effect of Curcuma longa on Newcastle disease virus in different times on Vero cell for cell free and cell associated virus. In healthy vero cells with $80-90 \%$ confluence $100 \mu \mathrm{l}$ of NDV of $7 \log 10$ TCID50 and $100 \mu 1$ of Curcuma longa at concentration $0.25 \%$ were added. The plates were incubated in $\mathrm{CO} 2$ incubator at $37^{\circ} \mathrm{C}$ and $\mathrm{CO} 25 \%$. Cell free and cell associated virus was harvested after $10 \mathrm{~min} ., 20$ min. , 40 min., 1h , 2h, 6h, 12 h, 24 h, 48 h, 72 h, $96 \mathrm{~h}$ and $120 \mathrm{~h}$ after incubations and titrated according to (Reed and Munch, 1938).

Experimental design. A total number of three hundred chicks one day old were used in this studies. The used chicks were divided into seven separate groups and treated as in (Table 1). Group (1) Fed commercial ration from one- day old till day of infection with NDV. Group (2) Fed commercial ration contained of curcuma longa, from one day till infection with VV NDV. Group (3) Fed commercial ration contained $0.5 \%$ Curcuma longa from one-day old till infection with VV NDV.

Group (4) Fed commercial ration from one- day old till infection with VV NDV, than fed on ration contained $1 \%$ of commercial Curcuma longa (as treatment ). Group (5) Fed commercial ration from one- day old till infection with VV $\mathrm{NDV}$, than fed on ration contained $0.5 \%$ of commercial Curcuma longa (treatment).| Group (6) Fed commercial ration contained $1 \%$ of commercial Curcuma longa and not infected. Group (7) Fed commercial ration and not infected (control negative). Blood samples were taken from chicks of each group at age 7, 10, 12 and 15 day old to detect the level of maternal HI antibodies to NDV. After withdrawal of maternal Abs, Group 1, group 2, group 3, group 4 and group 5 had been infected with VVNDV by a dose of $0.5 \mathrm{ml} /$ bird containing $10^{6} \mathrm{EID}_{50}(\mathrm{I} / \mathrm{M})$, infected chickens were observed daily and clinical signs were recorded. The number of dead and live chicks was recorded. Blood sample were taken from live chicks and their sera were separated and tested by HI test.

Haemagglutination test (HA) and Haemagglution inhibition test. They were done according to the slandered procedure by (Anon, 1971).

Determination of total protein, albumin and globulin. Total protein, albumen and globulin were performed according to (Burtis, 1999) while $\mathrm{A} / \mathrm{G}$ ratio was performed according to (Joce, 1999).

\section{Results and Discussion}

Newcastle disease (ND) is a highly contagious and fatal destructive disease, which attacks chiefly chickens and turkeys usually in acute form, but some time in sub acute or chronic form, This virus belongs to the genus Avulavirus in the family Paramyxoviridae (Houston, 2002).

During the last 25 years, there have been numerous broad-based screening programmes initiated in different parts of the globe to evaluate the antiviral activity of medicinal plants for in vitro and in vivo assays.

Many traditional medicinal plants have been reported to have strong antiviral activity and some of them have already been used to treat animals and people who suffer from viral infection (Hudson, 1990; Venkateswaran et al., 1987; Thyagarajan et al., 1988, 1990). This work aims to study the effect of cheep and natural herbal medicinal plant, known as Curcuma longa, on NDV in infected cell culture and chicken.

Turmeric consists of $3-5 \%$ curcuminoids. Curcumin which is the most important fraction responsible for the biological activities of turmeric. 
Table (2): Detection of 50\% toxic dose of Curcuma longa on vero cells.

\begin{tabular}{ccccc}
\hline Conc. Of plant $\% \mathrm{mg} / 100 \mathrm{ml}$ & \multicolumn{5}{c}{ Grade of CPE } \\
\cline { 2 - 5 } 0.25 & After 24 hrs & After 48 hrs & After 72 hrs & After 96 hrs \\
\cline { 2 - 5 } 0.5 & - & - & - & - \\
1 & - & - & + & + \\
2 & + & + & ++ & ++ \\
3 & + & + & ++ & ++ \\
\hline
\end{tabular}

Table (3): The effect of Curcuma longa on Newcastle disease virus at different time interval.

\begin{tabular}{|c|c|c|c|c|c|c|c|c|}
\hline \multirow[t]{2}{*}{ Hours of infection } & \multicolumn{4}{|c|}{$\begin{array}{l}\text { Intensity of CPE of infected, infected and } \\
\text { treated cells }\end{array}$} & \multicolumn{4}{|c|}{$\begin{array}{l}\text { vero cells infected with NDV and treated } \\
\text { with Curcuma longa }\end{array}$} \\
\hline & + & ++ & ++++ & ++++ & + & ++ & +++ & ++++ \\
\hline 12 & $\bullet$ & & & & o & o & $\circ$ & o \\
\hline 24 & & $\bullet$ & & & $\circ$ & $\circ$ & $\circ$ & $\circ$ \\
\hline 48 & & & ..• & & $\circ$ & $\circ$ & $\circ$ & $\circ$ \\
\hline 72 & & & $\bullet \bullet$ & & $\circ$ & $\circ$ & $\circ$ & $\circ$ \\
\hline 96 & & & & œ.• & $\circ$ & $\circ$ & $\circ$ & $\circ$ \\
\hline 120 & & & & •..• & $\circ$ & $\circ$ & $\circ$ & $\circ$ \\
\hline
\end{tabular}

$\circ$ :- $\quad$ no cytopatheic effect on Vero cell

- :- showing focal rounding and shrinkage of the infected cells

-• :- Beginning of cytoplasmic fusion which results in syncytial formation

... :- Large cytoplasmic vacuoles develop in the multinucleated cells or syncytia (poly-karyons)

.... :- Cell detachment and destruction of cells

Table (4): Titration of Newcastle diseases virus + curcuma longa $0.25 \%$ on Vero cells.

\begin{tabular}{|c|c|c|c|c|}
\hline \multirow[t]{2}{*}{ Time } & \multicolumn{4}{|c|}{ Virus titer $\left(\log _{10}\right.$ TCID50 $\left./ \mathrm{ml}\right)$} \\
\hline & \multicolumn{2}{|c|}{$\begin{array}{c}\text { Cell free virus (CFV) } \\
\log _{10} \text { reduction }\end{array}$} & \multicolumn{2}{|c|}{$\begin{array}{c}\text { Cell associated virus (CAV) } \\
\log _{10} \text { reduction }\end{array}$} \\
\hline 0 Min. & 7 & 0 & 0 & 0 \\
\hline $10 \mathrm{Min}$. & 5 & 2 & 0 & 7 \\
\hline 20 Min. & 5 & 2 & 0 & 7 \\
\hline 40 Min. & 4 & 3 & 2 & 5 \\
\hline $1 \mathrm{~h}$ & 2 & 5 & 4 & 3 \\
\hline $2 \mathrm{~h}$ & 1 & 6 & 5 & 2 \\
\hline $6 \mathrm{~h}$ & 1 & 6 & 2 & 5 \\
\hline $12 \mathrm{~h}$ & 0 & 7 & 2 & 5 \\
\hline $24 \mathrm{~h}$ & 0 & 7 & 2 & 5 \\
\hline $48 \mathrm{~h}$ & 0 & 7 & 2 & 5 \\
\hline $72 \mathrm{~h}$ & 0 & 7 & 0 & 7 \\
\hline $96 \mathrm{~h}$ & 0 & 7 & 0 & 7 \\
\hline $120 \mathrm{~h}$ & 0 & 7 & 0 & 7 \\
\hline
\end{tabular}

Table (5): Immunoflourscent test.

\begin{tabular}{|c|c|c|}
\hline $\begin{array}{l}\text { Hours of } \\
\text { infection }\end{array}$ & $\begin{array}{l}\text { Intensity of fluorescent in Vero cells infected } \\
\text { with NDV and treated with Curcuma longa }\end{array}$ & $\begin{array}{l}\text { Intensity of fluorescent in Vero cell } \\
\text { infected with NDV }\end{array}$ \\
\hline 1 & \pm & \pm \\
\hline 3 & $\overline{+}$ & $\overline{+}$ \\
\hline 6 & - & +++ \\
\hline 12 & - & +++ \\
\hline 24 & - & +++ \\
\hline 48 & - & +++ \\
\hline 72 & - & ++ \\
\hline 96 & - & ++ \\
\hline 120 & - & ++ \\
\hline
\end{tabular}



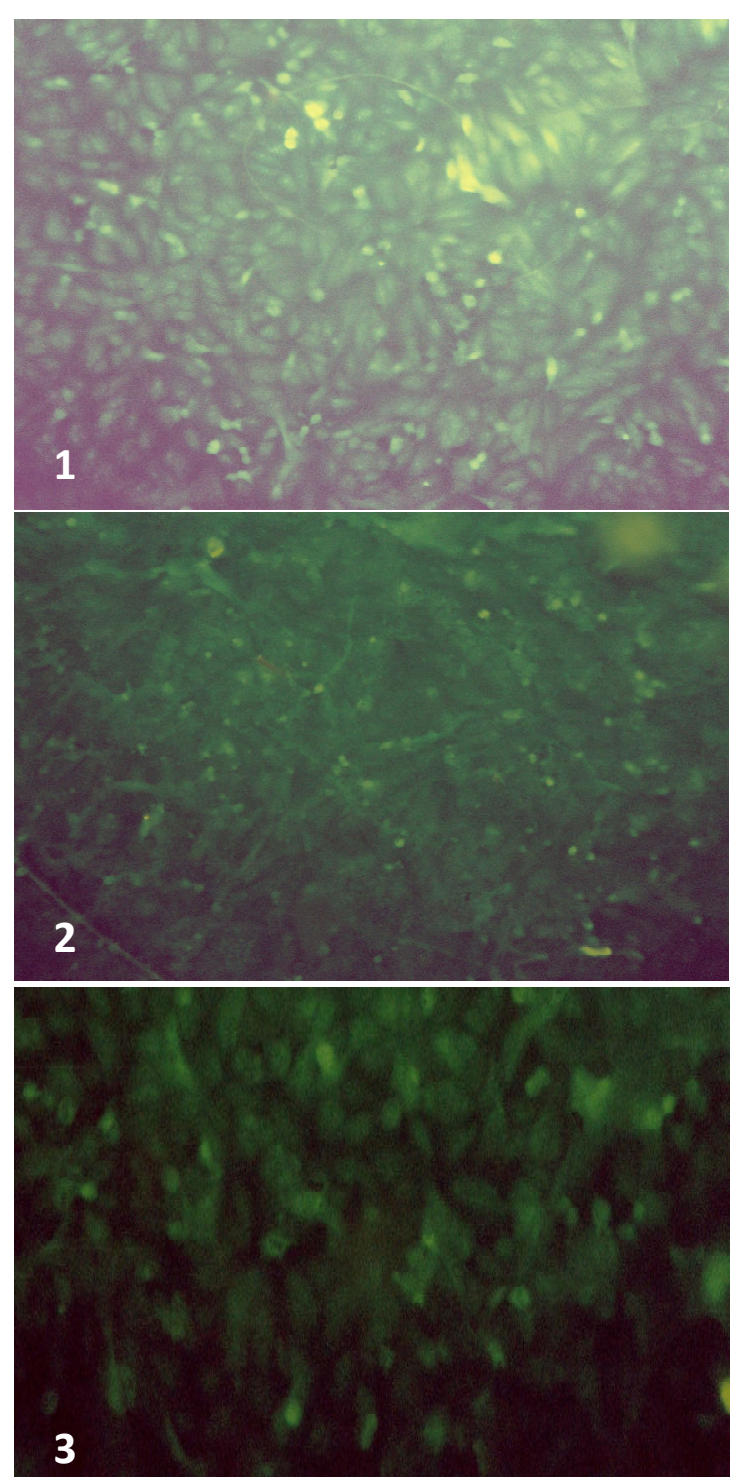

Fig.(1): Vero cell infected with NDV and stained with fluorescent showed fluorescent foci after $24 \mathrm{~h}$ (X200).

Fig.(2): Vero cell infected with NDV and treated with Curcuma longa showed small fluorescent foci after $3 \mathrm{~h}$ (X200).

Fig.(3): Vero cell infected with NDV and treated with Curcuma longa stained with fluorescent after 24h (X200).

The active constituents of turmeric are the flavonoid curcumin and volatile oils including tumerone, atlantone, and zingiberone. Other constituents include sugars, proteins, and resins. The best-researched active constituent is curcumin, which comprises 0.3 to 5.4 percent of raw turmeric (Leung, 1980).

Curcumin (diferuloylmethane), is a natural polyphenolic compound extracted from the spice turmeric, has been reported to have anti- inflammatory, antioxidant, and anti proliferative properties by modulating multiple cellular machineries. It inhibits several intracellular signaling pathways, including the mitogenactivated protein kinases (MAPKs) and casein kinase II (CKII), in various cell types (Subhash et al., 2007).

In this study, the efficacy of curcuma longa as natural antiviral product was estimated by using RNA virus model (NDV). For studying the antiviral activity of Curcuma longa, firstly we determine its toxicity on Vero cell culture using different concentration of the plant. Data presented in (Table 2) showed that low concentration of Curcuma longa $0.25 \%$ did not induce any CPE on vero cells culture up to $96 \mathrm{~h}$ PI while the concentration of $0.5 \%$ and $1 \%$ did not induce CPE in the first $24 \mathrm{~h}$ but death of cells was appeared after that denoting to the toxic effect of Curcuma longa in using these concentrations. Therefore we used low concentration of Curcuma longa $0.25 \%$ to evaluate its antiviral activity against NDV on Vero cells.

The antiviral activity of Curcuma longa on NDV was detected either qualitatively or quantitatively. Data presented in (Table 3) showed that Curcuma longa in concentration $0.25 \%$ has the ability to prevent cytopathogencity of NDV on vero cells after $12 \mathrm{~h}$ till $120 \mathrm{~h}$ PI.

For quantitative estimation of this effect, data presented in (Table 4) showed the result of titration of NDV in CFV and CAV when treated with $0.25 \%$ Curcuma longa. Curcuma longa inhibited the replication of NDV as the infectivity titer of the virus was decreased $2 \log$ ${ }_{10} 2 \mathrm{hrs}$ post infected (CAV) and $5 \log _{10}$ at $6 \mathrm{hrs}$ post infected (CAV) till $48 \mathrm{~h}$ post infection then decreased $7 \log 10$ after $72-120$ h post infection . The cell free virus (CFV) didn't found in tissue culture medium after $12 \mathrm{~h}$ post infection. The absence of CFV in treated sample $12 \mathrm{~h}$ PI and no CAV was detected $72 \mathrm{~h}$ PI beside the decrease in NDV infectivity titers may be attributed to the action of curcuma that strongly reduced viral RNA expression or synthesis of viral proteins. The inhibitory effect of Curcuma longa may be due to the inhibition of replication of viral genome, protein synthesis, virus assembly, virus release and virus titer and these results agree with (Xiaoning et al., 2007) who found that treatment with curcumin significantly 
Table (6): The effect of Curcuma longa on chicken infected with Newcastle virus.

\begin{tabular}{|c|c|c|c|c|c|c|c|c|c|c|}
\hline \multirow{3}{*}{ group } & \multirow{3}{*}{$\begin{array}{c}\text { Number } \\
\text { of bird } \\
\text { examined }\end{array}$} & \multicolumn{8}{|c|}{ Week post treatment } & \multirow{3}{*}{$\begin{array}{c}\text { protection } \\
\%\end{array}$} \\
\hline & & \multicolumn{2}{|c|}{$1^{\text {st }}$ week } & \multicolumn{2}{|c|}{$2^{\text {nd }}$ week } & \multicolumn{2}{|c|}{$3^{\text {rd }}$ week } & \multicolumn{2}{|c|}{$4^{\text {th }}$ week } & \\
\hline & & live & dead & live & dead & live & dead & live & dead & \\
\hline 1 & 50 & 20 & 30 & 10 & 10 & 6 & 4 & 4 & 2 & 8 \\
\hline 2 & 50 & 50 & 0 & 47 & 3 & 45 & 2 & 45 & 0 & 90 \\
\hline 3 & 50 & 45 & 5 & 40 & 5 & 40 & 0 & 40 & 0 & 80 \\
\hline 4 & 50 & 35 & 15 & 30 & 5 & 28 & 2 & 28 & 0 & 56 \\
\hline 5 & 50 & 30 & 20 & 27 & 3 & 25 & 5 & 20 & 0 & 40 \\
\hline 6 & 25 & 25 & 0 & 25 & 0 & 25 & 0 & 25 & 0 & 100 \\
\hline 7 & 25 & 25 & 0 & 25 & 0 & 25 & 0 & 25 & 0 & 100 \\
\hline
\end{tabular}

Table (7): Geometric Mean of NDV HI antibody titers on different groups.

\begin{tabular}{ccccc}
\hline \multirow{2}{*}{ Groups of chicks } & \multicolumn{5}{c}{ Geometric mean of HI antibody titers per weeks after challenge } \\
\cline { 2 - 5 } & $\mathbf{1}$ & $\mathbf{2}$ & $\mathbf{3}$ & $\mathbf{4}$ \\
\hline 1 & 128 & 1024 & 4096 & 512 \\
2 & 32 & 16 & 8 & 8 \\
3 & 64 & 32 & 16 & 16 \\
4 & 128 & 64 & 32 & 16 \\
5 & 128 & 64 & 64 & 32 \\
6 & 0 & 0 & 0 & 0 \\
7 & 0 & 0 & 0 & 0 \\
\hline
\end{tabular}

Table (8): The effect of Curcuma longa on total protein, albumin and globulin of treated chicks.

\begin{tabular}{llccccccc}
\hline Week & Parameter & Group 1 & Group 2 & Group 3 & Group 4 & Group 5 & Group 6 & Group7 \\
\hline $1^{\text {st }}$ week & T.P. & 2.76 & 3.36 & 3.08 & 2.88 & 2.84 & 3.6 & 3.2 \\
& Albumin & 1.06 & 1.92 & 1.8 & 1.4 & 1.4 & 1.96 & 1.78 \\
& Globulin & 1.69 & 1.44 & 1.28 & 1.52 & 1.4 & 1.6 & 144 \\
& A.G.ratio & 0.62 & 1.32 & 1.25 & 0.8 & 0.94 & 1.22 & 1.094 \\
$2^{\text {nd }}$ week & T.P. & 2.64 & 3.64 & 3.56 & 3.04 & 3 & 3.64 & 3.2 \\
& Albumin & 0.84 & 1.8 & 1.8 & 1.44 & 1.44 & 2.04 & 1.7 \\
& Globulin & 1.8 & 1.84 & 1.8 & 1.52 & 1.48 & 1.6 & 1.48 \\
& A.G.ratio & 0.4 & 1.1 & 1.1 & 0.92 & 0.9 & 1.2 & 1 \\
$3^{\text {rd }}$ week & T.P. & 2.4 & 3.76 & 3.72 & 3.32 & 3.2 & 4.08 & 3.16 \\
& Albumin & 0.64 & 1.92 & 1.92 & 1.76 & 1.76 & 2.12 & 1.64 \\
& Globulin & 1.84 & 1.84 & 1.8 & 1.52 & 1.6 & 1.96 & 1.56 \\
& AG ratio & 0.3 & 1.04 & 1.06 & 1.1 & 1.1 & 1.08 & 1.02 \\
$4^{\text {th }}$ week & T.P. & 2.44 & 3.76 & 3.72 & 3.36 & 3.2 & 4.14 & 3.2 \\
& Albumin & 0.95 & 1.92 & 1.84 & 1.76 & 1.76 & 2.12 & 1.72 \\
& Globulin & 1.22 & 1.84 & 1.8 & 1.6 & 1.6 & 2 & 1.6 \\
& A/G ratio & 0.8 & 1.04 & 1.06 & 1.1 & 1.1 & 1.06 & 1.01 \\
\hline
\end{tabular}

reduced viral RNA expression, protein synthesis, and virus titer and protected cells from virusinduced cytopathic effect and apoptosis. This result was confirmed by IFA test on Vero cell culture (Table 5, Fig.1-3). The inhibition of NDV proteins may be due to either prevention of viral protein synthesis or prevention of ribosomal activities (Xiaoning et al., 2007). Thus, our results suggest an important antiviral effect of Curcuma longa wherein it potently inhibits replication of NDV and accumulation of its proteins as detected by IFA during comparing the infected and treated cells with curcuma Longa with infected untreated cells.
An experimental design for studying the antiviral activities of Curcuma longa against NDV in Vivo was planned .A total number of three hundred chicks one day old were used in this studies and the date presented in (Table 6) revealed clearly that that chicks treated and infected with $1 \%$ Curcuma longa as a prophylactic dose showed higher protection rate $(90 \%)$ while the chicks that treated with $0.5 \%$ and infected showed protection rate $(80 \%)$. Chicks that infected without treatment with Curcuma longa showed lower protection rate $(8 \%)$. The chicks infected then treated with 1\% Curcuma longa as treatment dose showed protection 
$(65 \%)$ and the chicks infected then treated with $0.5 \%$ Curcuma longa showed protection( $40 \%$ ), while chicks infected and not treated showed lowest protection ( $8 \%$ ) as $92 \%$ of the infected chicken were died. Theses results are in agreement with (Sebla et al., 2007) who found that curcumin inhibits herpes simplex virus. Hye et al. (2009) also found that Curcuma longa extract has antiviral effect against hepatitis B virus replication. And the result where confirmed by HI titer in (Table 7). It is very clear that the NDV HI antibody titers increased gradually from the first week till $3^{\text {rd }}$ week (maximum value) and then decreased gradually.

On measuring total protein, albumin and globulin fraction in sera of different chicken groups data present in (Table 8) showed higher total serum protein 3.72 in Curcuma longa treated group than other groups, also significant higher globulin fraction 1.84, and 1.8 in curcuma longa treated group than other non treated while group 1 that infected with NDV without treatment showed decrease in both total protein and albumin .This result agree with (Shabon, 2007) who recorded that curcuma was found to elevate the protein profile total protein, albumin and globulin.

From all previous discussed data we could conclude the anti-NDV activity of Curcuma longa and we recommended the use of Curcuma longa as feed additives for its antiviral activity and immune stimulating effect.

\section{References}

Anon, (1971): Methods for examining poultry biologics and for identifying \& quantifying avian pathogens. National Academy of Science Wahington D.C.

Burtis, A. (1999): Tietz Texbook of clinical chemistry $.3^{\text {rd }}$ ed AACC.

Houston, (2002): Over expression of NDV protein enhances Arch Virol., 147(1):1071-1076.
Hudson, J. B. (1990): Antiviral Compounds from Plants. nBoca Raton, Ann Arbor, Boston.

Hye, J. K.; Hwa, S. Y.; Jin, C. K.; Chan, S. P.; Mi, S. C.; Mijee, K.; Hyangsoon, C.; Jung, S. M.; Yong, S. K.; Seong, W. Y. and Jeong K. A. (2009): Antiviral effect of Curcuma longa Linn extract against hepatitis B virus replication( ${ }^{\mathrm{a} D e p a r t m e n t}$ of Microbiology, Chungnam National Univ., Daejeon 305-764, South Koreaprotease. Phytotherapy Res., 14:510-516.

Joce, L. K. (1999): laboratory diagnostic tests with nursing impacation $5^{\text {th }}$ ed.

Leung, A. (1980): Encyclopedia of Common Natural Ingredients Used in Food, Drugs, and Cosmetics. New York, NY: John Wiley 313-314.

Reed L. J. and Muench, H. (1938): Simple method of estimating fifty precent end points. Am. J. Hyg., 27:493497.

Sebla, B. K.; James, D.; Martha, E. R. and Steven J. T. (2007): Curcumin inhibits herpes simplex virus immediateearly gene expression by a mechanism independent of p300/CBP histone acetyltransferase activity. 373(2):239247.

Shabon, M. H. (2007): Radioorotective effect of curcuma. National Centre for Nuclear Safety and Radiation Control, Atomic Energy Authority, Cairo, Egypt.

Stone, H. D.; Mitchell, B. and Brugh, M. (1997): In ovo vaccination ofchicken embryos with experimental Newcastle disease and avian influenza oil - emulsion vaccines . Avian Dis., 41(4):856.

Subhash, C. G.; Xiaohua, G. and Scott, D. (2007): Immunodulation by curcumin 10.1007/978-0-387-4640-514

Thyagarajan, S. P.; Subramanian, S.; Thiranapasundaru, T.; Venkateswaran, P. S. and Blumberg, B. S. (1988): Effect of Phyllanthus amarus on chronic carriers of hepatitis B virus. Lancet, 2:764-766.

Thyagarajan, S. P.; Subramanian, S.; Thiranapasundaru, T.; Thyagarajan, S. P.; Jayaram, S. and Valliammai, T. (1990): Phyllanthus amarus and hepatitis B (Letter). Lancet, 336:49-50.

Venkateswaran, P. S.; Millman, I. and Blumberg, B. S. (1987): Effects of an extract from Phyllanthus niruri on hepatitis B and Woodchuck hepatitis viruses: in vitro and in vivo studies. Proceedings of the National Academy of Sciences of the USA 84, 274- 278.

Xiaoning, S.; Yahong, W.; Jerry Wong, Jingchun Z.; Bruce, M. M. and Honglin, L. (2007): Curcumin inhibits replication of CVB3.

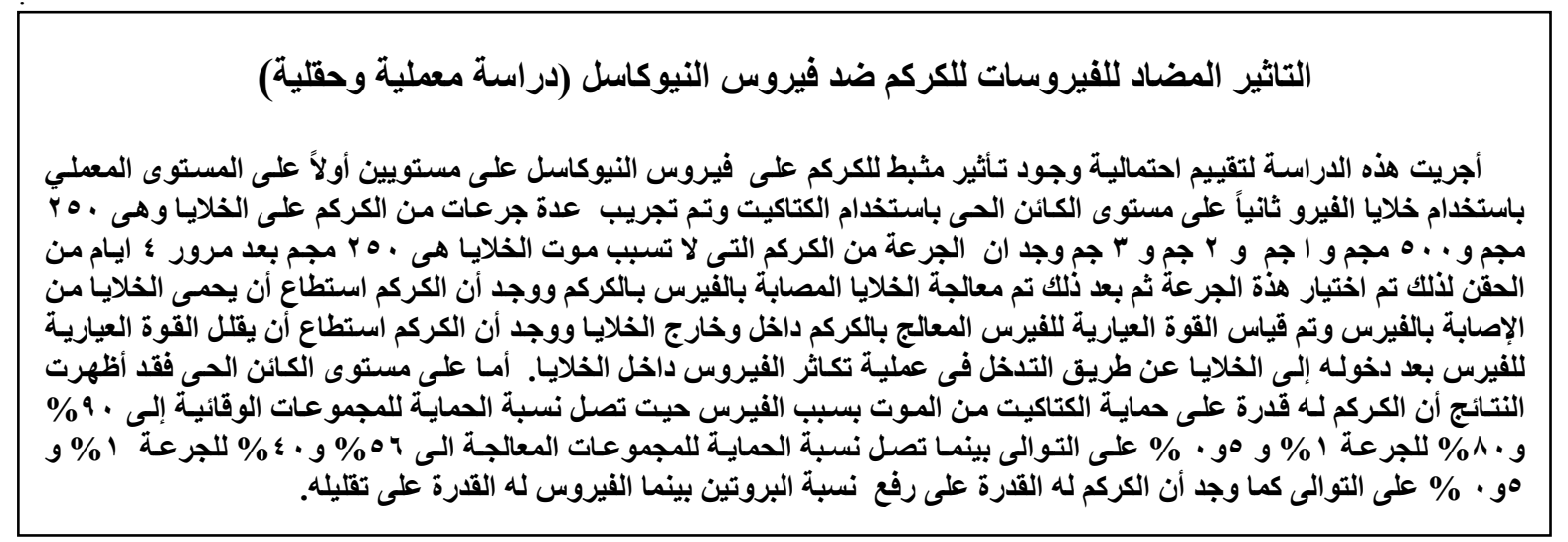

